\title{
Sol-gel and peptides: An attractive route to unprecedented biomaterials
}

\author{
Gilles Subra ${ }^{1}$, Laurine $\operatorname{Valot}^{1}$, Manon Maurel ${ }^{1}$, Titouan Montheil ${ }^{1}$, Cécile Echalier ${ }^{1}$, Muriel Amblard ${ }^{1}$, Danièle Noël ${ }^{2}$, \\ Marie Maumus ${ }^{2}$, Tao Jia ${ }^{3}$, Jean-Luc Coll ${ }^{3}$, Ahmad Mehdi ${ }^{4}$, Jean Martinez ${ }^{1}$ \\ ${ }^{1}$ Institute of Biomolecules Max Mousseron, France \\ ${ }^{2}$ Institute of Regenerative Medicine and Biotherapies, France \\ ${ }^{3}$ Institute of Advanced Biotechnologies, France \\ ${ }^{4}$ Institute Charles Gerhardt, France
}

https://doi.org/10.17952/35EPS.2018.028

Affording biological properties to a material is one of the challenges the chemists have to tackle, to improve the efficiency of existing devices and also to propose new biomaterials. Most of synthetic approaches to obtain functional materials rely on non-covalent coatings or post-grafting realized by multistep ligation chemistry. In this context, we envisioned a bottom-up strategy to introduce bioactive peptides in polymers or materials and in particular to prepare hydrogels. [1-3]

\section{A bottom-up approach to mimic extracellular matrix}

Extracellular matrix (ECM) is a complex and bioactive scaffold offering a physical support for cells but also providing the chemical and mechanical signals cells need to migrate, differentiate and grow properly. Hydrogels have been investigated as artificial ECM for 3D-cell culture, tissue engineering or regenerative medicine and are of paramount interest for bioink design. [4]

Natural biopolymers (e.g. collagen, gelatin, hyaluronic acid, alginate) are bioactive and biocompatible. However due to their natural origin, they present a poor batch-to-batch reproducibility and may lead to safety issues (immunogenicity, biocontamination). Their large-scale production can be difficult. Moreover, biopolymers are mostly used as physical hydrogels meaning that they have to be chemically cross-linked for long-lasting tissue engineering applications where the hydrogel is supposed to behave as support of cells for weeks. In contrast, several biocompatible synthetic polymers (e.g. PEG, PVA, Pluronic) are produced (even in large scale) with a good reproducibility and offering a large panel of molecular weight/chain sizes in order to tune their properties. Unfortunately they are bioinert (they are called 'permissive hydrogels') in a sense that they do not give any biologically relevant signaling to cells and have to be further functionalized to acquire suitable bioactivity. They also need to be cross-linked to form a 3D hydrogel network. By the way, it requires selective chemical cross-linking reactions (e.g. thiol-ene reaction, acrylate cross-linking) which may ideally proceed biorthogonally in the presence of other fragile biomolecules and eventually cells (if the hydrogel is a bioink for $3 \mathrm{D}$ biofabrication). At last, small organic gelators and in particular self-assembling peptides have also been described (betasheets KLD-12 [5]; RADA16 [6]; FEFQFK [7]; betahairpin VKVKVKVKvPPTKVEVKVKV [8] ; foldamers ( $\beta 3 \mathrm{AA}) 3$ [9]). They present many advantages such as easy synthesis, shear-thinning behavior (injectability), biocompatibility and could be used as drug delivery platform. Unfortunately, they are bioinert and their further functionalization may disrupt their self-assembly. Moreover, once implanted, dilution in biological fluids induce rapid disassembly of the structure which is a strong limitation as their mechanical properties cannot be easily tuned. 


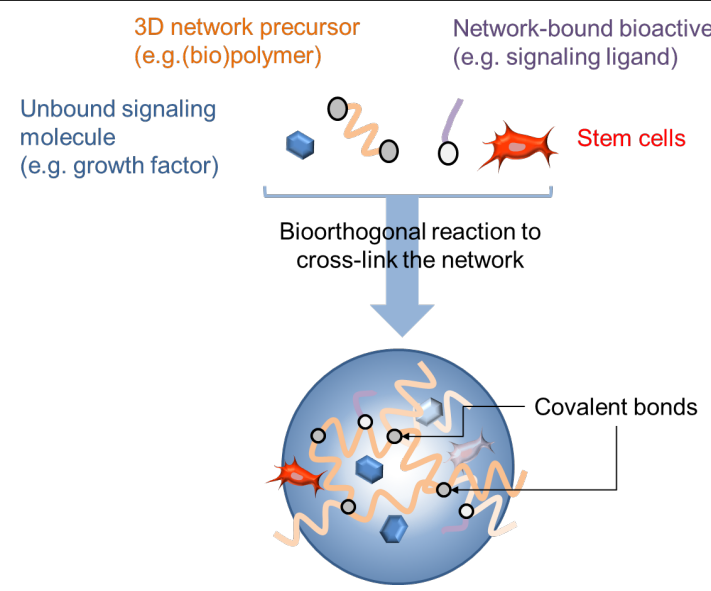

Figure 1: Hybrid hydrogel composition

In that context, we developed chemical hydrogels, obtained via a block-wise approach offering a degree of flexibility required to mimic different ECM compositions (Fig. 1). The bioorthogonal reaction creating the 3D network is driven by hydrolysis and condensation of alkoxysilanes moieties connected the different hydrogel components. The hydrolysis and condensation of such moieties proceeds chemoselectively, at room temperature or $37^{\circ} \mathrm{C}$ and is compatible with the side-chains of biomolecules. Interestingly, any type of peptides but also biopolymers and dyes can be silylated and thus can participate to the covalent formation of the material. We already used this sol-gel process to prepare peptide-functionalized fluorescent silica nanoparticles [10,11], grafting of wound-healing or antibacterial peptides on silicone catheter,[12] dressings [13] and titanium [14] and comb-like and silicone linear polymers were prepared. [15,16]

At $\mathrm{pH} 7$, the sol gel process needs to be catalyzed with a nucleophilic compound to faster the gelation. We selected sodium fluoride at low and non-toxic concentration $(<0.3 \mathrm{mg} / \mathrm{ml})$ to perform the hydrolysis of alkoxysilane and subsequent condensation reactions (Fig. 2).

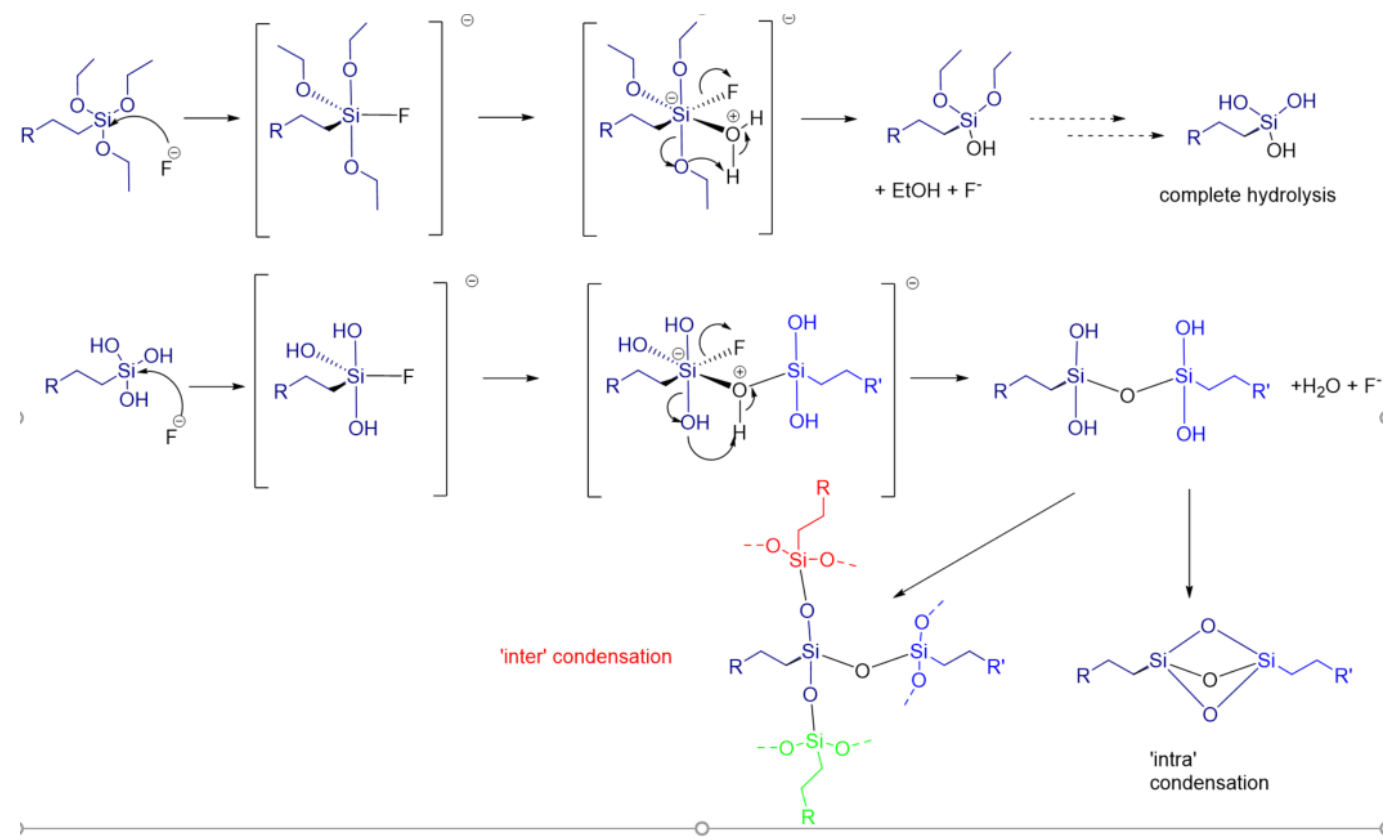

Figure 2: Proposed mechanism of fluoride catalyzed sol-gel process

\section{Peptide-modified PEG based hydrogels}

We first demonstrate the approach on PEG-based hydrogels. We synthesized bisilylated PEG, for the 'bricks' of the hydrogel network, and monosilylated RGD peptide (Fig. 3) as adhesion ligand for cells.[1] 

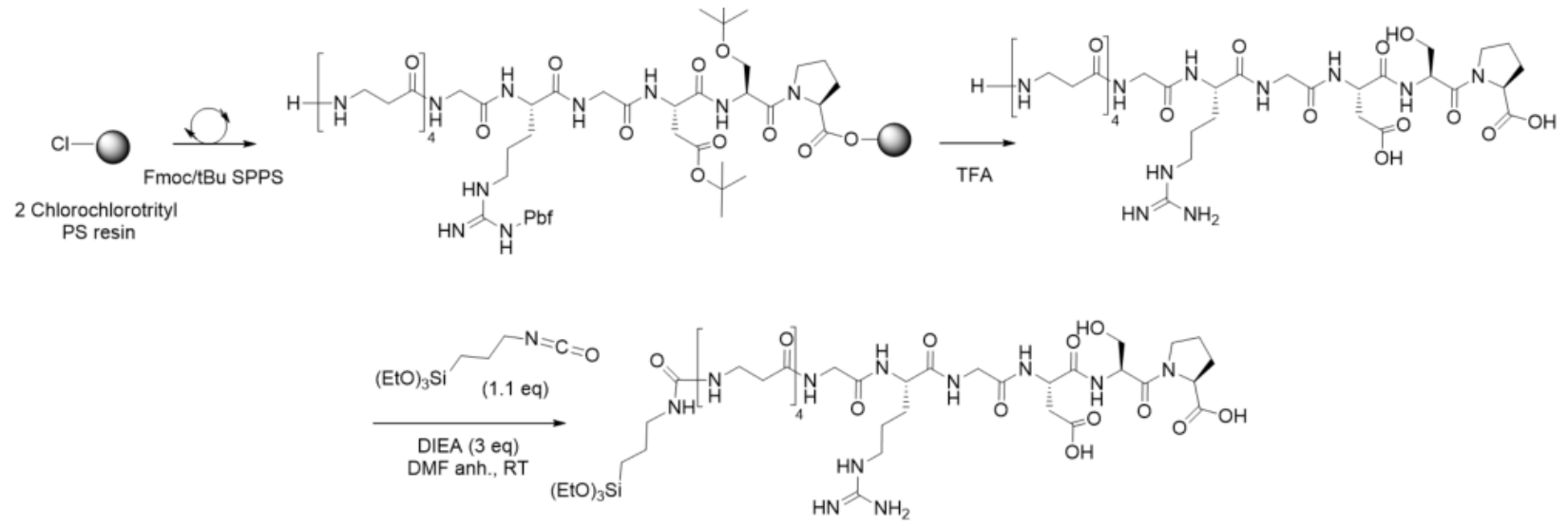

(EtO) $)_{3} \mathrm{Si}-\left(\mathrm{CH}_{2}\right)_{3}-\mathrm{NHCO}-(\beta \mathrm{Ala})_{4}$ GlyArgGlyAspSerPro-OH

Figure 3: Silylation of PEG and synthesis of silylated RGD peptide

Peptide-functional hydrogel was simply obtained by solubilizing the bisilylated PEG at $10 \%$ wt and the silylated RGD peptide at different concentrations (20 and $10 \mathrm{~mol} \%$ ) in phosphate buffer and in presence of NaF. After overnight gelation at $37^{\circ} \mathrm{C}$, L929 fibroblasts were seeded on the surface of RGD-functionalized hydrogel and non-functionalized hydrogel as a negative control. We observed that the cell adhesion of fibroblasts after 2 hours was strongly improved (over 5 times) on peptide functionalized-hydrogel.[1] Interestingly, we demonstrated that this hydrogel could be 3D-printed by an extrusion process (Biobot $13 \mathrm{D}$ printer), after reaching the appropriate viscosity (between 2500 and $4500 \mathrm{mPa} / \mathrm{s}$ ) during sol-gel condensation(Fig. 4).

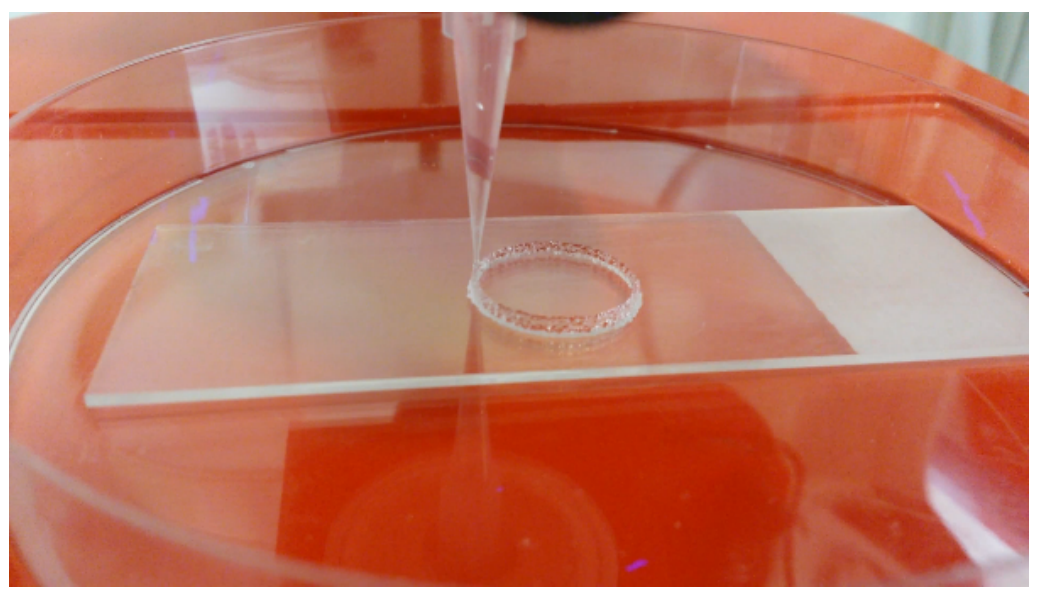

Figure 4: 3D printing of hybrid PEG hydrogel

\section{Collagen peptide-based hydrogels}

We wanted to replace the PEG by a more biomimetic building block. Collagen being the most abundant protein found in ECM, we chose to synthesize several peptides presenting the proline-hydroxyproline-glycine repetition unit (from 3 to 9 units) found in natural collagen sequence. Flanked by two lysine residues, these peptides were bis-silylated (Fig. 5).[3] 

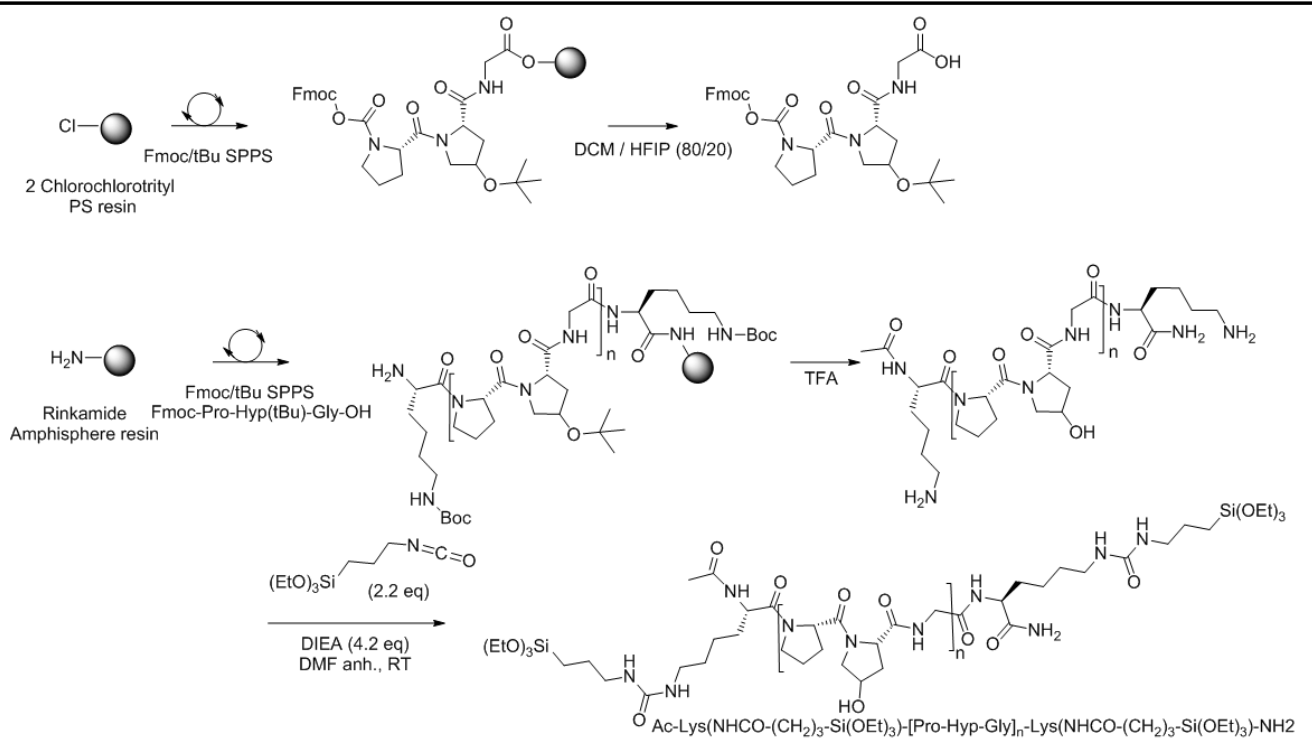

Figure 5: Synthesis of bisilylated collagen-like peptides

Hybrid peptide hydrogels were obtained by sol-gel process at 6-10 \%weight concentration. Noteworthy, we demonstrated that human mesenchymal stem cells (hMSC) could be seeded on the surface of hydrogels but also could be embedded directly in the solution during gelation with a good viability. The incorporationof silylated hyaluronic acid, peptide ligands and growth factors (TGF $\beta-3$ ) to mimic the ECM composition of cartilage is under investigation to induce the hMSC differentiation into chondrocytes for cartilage repair applications.

\section{References}

1. Echalier C, Pinese C, Garric X, Van Den Berghe H, Jumas Bilak E, Martinez J, Mehdi A, Subra G. Chem Mater. 2016; 28: 1261-1265.

2. Echalier C, Levato R, Mateos-Timoneda MA, Castano O, Déjean S, Garric X, Pinese C, Noël D, Engel E, Martinez J, Mehdi A, Subra G. RSC Adv. 2017; 7: 12231-12235.

3. Echalier C, Jebors S, Laconde G, Brunel L, Verdié P, Causse L, Bethry A, Legrand B, Van Den Berghe H, Garric X, Noël D, Martinez J, Mehdi A, Subra G. Mater Today.

4. Bronzino JD, Peterson DR. 2015; Fourth Edition: 114.

5. Kisiday J, Jin M, Kurz B, Hung H, Semino C, Zhang S, Grodzinsky AJ. Proc Natl Acad Sci. 2002; 99: 9996-10001.

6. Cheng T-Y, Chen M-H, Chang W-H, Huang M-Y, Wang T-W. Biomaterials. 2013; 34: 2005-2016.

7. Martin C, Oyen E, Mangelschots J, Bibian M, Ben Haddou T, Andrade J, Gardiner J, Van Mele B, Madder A, Hoogenboom R, Spetea M, Ballet S. Med Chem Commun. 2016; 7: 542-549.

8. Haines-Butterick L, Rajagopal K, Branco M, Salick D, Rughani R, Pilarz M, Lamm MS, Pochan DJ, Schneider JP. Proc Natl Acad Sci. 2007; 104: 7791-7796.

9. Luder K, Kulkarni K, Lee HW, Widdop RE, Del Borgo MP, Aguilar M-I. Chem Commun. 2016; 52: 4549-4552.

10. Jia T, Choi J, Ciccione J, Henry M, Mehdi A, Martinez J, Eymin B, Subra G, Coll J-L. Biomaterials. 2017.

11. Ciccione J, Jia T, Coll J-L, Parra K, Amblard M, Jebors S, Martinez J, Mehdi A, Subra G. Chem Mater. 2016; 28: 885-889.

12. Pinese C, Jebors S, Echalier C, Licznar-Fajardo P, Garric X, Humblot V, Calers C, Martinez J, Mehdi A, Subra G. Adv Healthc Mater. 2016; 5: 3067-3073. 
13. Pinese C, Jebors S, Stoebner P-E, Humblot V, Verdié P, Causse L, Garric X, Taillades H, Martinez J, Mehdi A, Subra G. Mater Today Chem. 2017; 4: 73-83.

14. Masurier N, Tissot J-B, Boukhriss D, Jebors S, Pinese C, Verdie P, Amblard M, Mehdi A, Martinez J, Humblot V, Subra G. J Mater Chem B. 2018.

15. Jebors S, Ciccione J, Al-Halifa S, Nottelet B, Enjalbal C, M'Kadmi C, Amblard M, Mehdi A, Martinez J, Subra G. Angew Chem Int Ed. 2015; 54: 3778-3782.

16. Jebors S, Pinese C, Nottelet B, Parra K, Amblard M, Mehdi A, Martinez J, Subra G. J Pept Sci. 2015; 21: 243-247. 